\title{
Analysis of Organizational Culture and Work Environment to the Satisfaction of Outpatients Room in Public Health Center of Bangsal Mojokerto Regency
}

\author{
Ulfah Kurniasari ${ }^{1}$, Koesnadi ${ }^{2}$, \\ Endra Widiyanto ${ }^{2}$ \\ ${ }^{1}$ Bangsal Public Health Center, \\ Mojokerto Regency \\ ${ }^{2}$ IIK STRADA Indonesia \\ Email: \\ britniaaaa@gmail.com
}

\begin{abstract}
The satisfaction of health care users is closely related to the results of health services, both medically and non-medically such as compliance with treatment. Problems regarding performance in Puskesmas Bangsal greatly impact the services provided to patients that can be seen from the decrease in the number of patient visits to upt Puskesmas Bangsal Mojokerto Regency. The purpose of this study was to find out the influence of organizational culture and work environment (temperature, air, noise, lighting) on the satisfaction of outpatients in Mojokerto District Ward Health Center The design of this research is analytics with a crossectional approach. The variables of this study are organizational culture and work environment (temperature, air, noise and lighting) as independent variables and satisfaction as dependent variables. The research population is all outpatients who visited the Outpatient Health Center Mojokerto in January - June 2020 as many as 1,984 outpatients. Samples were taken with random sampling techniques as many as 397 respondents. The data was collected with questionnaire instruments and processed using editing, coding, scoring and tabulating and tested with linear regression tests. The results of this study showed that partially or alone - independent variables can affect the occurrence of dependent variables due to the value of $<$ of 0.05 . Independent variables affecting simultaneously or together can affect patient satisfaction and the relationship between the two variables shows a close relationship with a coefficient value of $99.1 \%$. The results of this study show the organizational culture and work environment is one aspect of the management of health center services that can affect patient satisfaction in receiving services, so it is expected that management can improve these aspects optimally so that patient satisfaction can be further

improved.
\end{abstract}

Keywords: Organization culture, work environment, satisfaction, public health center
hey

Copyright @ 2021 IIK STRADA Indonesia All right reserved.

Received : March $8^{\text {th }} 2021$

Accepted : April 12 2021

Published : May $20^{\text {th }} 2021$

This is an open-acces article distributed under the terms of the Creative Commons Attribution-ShareAlike 4.0 International License.

\section{INTRODUCTION}

Public Health Center is a health service facility that operationally has services that are identical to service services, but the service can not be equated with services else place, this is because 
the services provided by the health center is a health service that has a special nature. On the other hand, hospitals as service providers must also implement social functions (Bima, 2017). According to Herawati and Qomariyah (2015) that puskesmas as a health institution with a mission to improve the degree of public health, play a role in maintaining and improving the degree of public health. The quality of service level to patient satisfaction is a complete process, so it will ultimately concern the management of the health center as a whole. Puskesmas management needs to be updated and improved, in order to realize quality health services, affordable, effective, and efficient, equitable and sustainable. Over time, science and technology experienced a very rapid development in the field of health, puskesmas required to improve the performance and quality in performing services to patients.

Patient satisfaction is a person's level of feeling after comparing the performance the patient feels with the expectations that the patient wants when he/she wants to seek treatment. If the patient is satisfied, this greatly affects an action based on past experience where they will not easily switch services due to marketing stimulation (Yulfita, 2016). Satisfaction is a person's pleasure that comes from the comparison between pleasure to activity and a product service with his expectations. This patient satisfaction can be created through good service by medical personnel in health institutions. Thus, if the service is not good, patients who are dissatisfied will file a complaint with the Puskesmas. Complaints that are not immediately handled will result in decreased patient satisfaction with the quality of health services in the institution (Winarsih. 2012). Patients will be satisfied if there are similarities between the expectations and the reality of health care obtained. The satisfaction of health care users is closely related to the results of health services, both medically and non-medically such as compliance with treatment, understanding of medical information and continuity of care (Kotler, 2014).

Problems regarding performance in Puskesmas Bangsal greatly impact the services provided to patients, this can be seen from the total number of outpatient visits in 2018 as many as 5,162 patients. The trend of visits in 2018 showed a decrease from the beginning of the year in January there were 685 paisen and a decrease in the number of patient visits to 332 paisen in December 2018. Meanwhile, the total number of outpatient visits in 2019 was 5,482 patients. The trend of visits in 2019 showed a decrease from the beginning of the year in January there were 785 patients and a decrease in the number of patient visits to 352 paisen in December 2019. The number of visits in January 2020 was 9,847 patients, while in February there were 10,377 patients and in March the number of paisen visits decreased to 9,433 patients and in April it decreased to 8,264 patients. Number of outpatient poly general patient visits in January -June 2020 as many as 1984 patients

The results of a preliminary study conducted on 10 respondents at BP Umum obtained data 6 respondents complained about the provision of services that are still not in accordance with the expectations of patients, such as hospitality of service personnel to patients, officers are less attentive to patients. 4 respondents stated that the officers had provided good service and patients were satisfied with the service.

Quality health services are health services that can satisfy every service user in accordance with the level of satisfaction of the average population and its implementation in accordance with the standards and codes of professional ethics that have been established (Azwar, 2011). The quality of service becomes important because it has a direct impact on the Puskesmas. Good quality of service will be an advantage for puskesmas. A puskesmas has got positive value in the eyes of consumers, then the consumer will provide good feedback, and it is not impossible to be a regular customer or repeat buyer. Therefore, it is very important to consider aspects of customer satisfaction related to the quality of service provided. Types of services that can be provided for example in the form of convenience, speed, ability, and hospitality are shown through attitudes and direct actions to consumers (Nilawati, 2019).

Kotler (2012), in his book "Marketing Management" said that satisfaction is the feeling of pleasure or disappointment of a person arising from comparing the perceived performance of the product or results against the expectations of service users (consumers). Customer satisfaction 
becomes a goal for companies engaged in health services such as hospitals in order to maintain customers and stimulate the emergence of interest in referencing to the public. According to Kotler (2012) mentioned five dimensions of service quality that must be met, namely tangible, empathy, reliability, responsiveness, assurance. The dimension of the service affects patient satisfaction with the services received. Organizational culture is one of the factors supporting the implementation of good service to the community. By applying good culture or rules and obeyed by all members of the organization, then automatically the service provided to the community will also be primed. In addition, if employees are given an understanding of organizational culture, each employee will be encouraged and motivated to perform their duties and functions, especially in providing services (Munanzar, 2019).

In addition to the organizational culture of the work environment can affect employee job satisfaction and also have an impact on customer satisfaction. The work environment is broadly divided into two, namely the physical work environment and the non-physical work environment. The physical work environment is a work environment consisting of equipment, usable office machinery and office layout that affects the physical work environment of the office as well as physical working conditions in conditions where work should be carried out (Moekijat, 2015). Puskesmas must be able to establish, provide and maintain the facilities needed to achieve the suitability of product or service requirements, including facilities as applied to buildings, workspaces and related facilities, process equipment and other support services (Hermanto, 2016). Facilities related to work is a physical means that can process an input to the desired output, and the availability of these facilities can facilitate work and fun for users such as facilities of places of worship, medical guarantees, old age guarantees and so on (Sari, 2016).

Public Health center is expected to be the spearhead of the implementation of health services in an area and is a unit of organization that is comprehensive and integrated closest to the community. The role and function of puskesmas is very strategic in health development in Indonesia. Puskesmas plays a role in organizing health efforts to increase awareness, willingness, and ability to live a healthy life for each population in order to obtain an optimal degree of health (Ministry of Health RI 2011).

Based on this background, researchers are interested to submit research proposals on "The influence of organizational culture and work environment (temperature, air, noise, lighting) on the satisfaction of outpatients in Mojokerto District Ward Health Center

\section{MATERIALS AND METHODS}

The design of this research is analytics with a crossectional approach. The variables of this study are organizational culture and work environment (temperature, air, noise and lighting) as independent variables and satisfaction as dependent variables. The research population is all outpatients who visited the Outpatient room in Bangsal Public Health Center Mojokerto in January June 2020 as many as 1,984 outpatients. Samples were taken with random sampling techniques as many as 397 respondents. The data was collected with questionnaire instruments and processed using editing, coding, scoring and tabulating and tested with linear regression tests. This Tesis also have etichal approval wint number of certificate are 2098/KEPK/VIII/2020. 


\section{RESULT}

\section{Partial Analysis}

Table 1 Partial liner regersi analysis (t test) influence of organizational culture and work environment on patient satisfaction at Bangsal Public Health Center Of Mojokerto Regency in October $2020(n=397)$

\begin{tabular}{lcc}
\hline \multicolumn{1}{c}{ Criteria } & t test Value & P value \\
\hline Organization Culture & 21.213 & 0.000 \\
Temperature & 5.123 & 0.003 \\
Air & 3.524 & 0.001 \\
Noise & 3.262 & 0.008 \\
\hline Lighting & 4.649 & 0.007 \\
\hline
\end{tabular}

Based on the results in table 1 shows that the $\mathrm{p}$ value of both independent variables (Organizational culture and work environment) is less than 0.05 so that partially or on its own independent variables (Organizational culture, temperature, air, noise and lighting) affect patient satisfaction.

\section{Simultan Analysis}

Tabel 2 Simultan liner regersi analysis (F test) influence of organizational culture and work environment on patient satisfaction at Bangsal Public Health Center Of Mojokerto Regency in October $2020(n=397)$

\begin{tabular}{|c|c|c|c|c|c|c|}
\hline Model & & Sum of Squares & df & Mean Square & $\mathrm{F}$ & Sig. \\
\hline \multirow[t]{3}{*}{1} & Regression & 112589.014 & 5 & 22517.803 & 9092.100 & $.000^{\mathrm{b}}$ \\
\hline & Residual & 968.364 & 391 & 2.477 & & \\
\hline & Total & 113557.377 & 396 & & & \\
\hline
\end{tabular}

a. Dependent Variable: Satisfaction

b. Predictors: (Constant), Organizational Culture, Work Environment)

Based on the results in table 2 shows that the significance value shows a value $=0.000$ which means less than 0.05 so that it can be expressed simultaneously or simultaneously independent variables (Organizational culture, temperature, air, noise and lighting) affecting patient satisfaction.

\section{Determination Coefficient}

Tabel 3 Determination Coefficient liner regersi analysis about influence of organizational culture and work environment on patient satisfaction at Bangsal Public Health Center Of Mojokerto Regency in October $2020(n=397)$

\begin{tabular}{llcccc}
\hline $\begin{array}{l}\text { Mode } \\
1\end{array}$ & $\mathrm{R}$ & R Square & $\begin{array}{c}\text { Adjusted R } \\
\text { Square }\end{array}$ & $\begin{array}{c}\text { Std. Error of the } \\
\text { Estimate }\end{array}$ & $\begin{array}{c}\text { Durbin- } \\
\text { Watson }\end{array}$ \\
\hline 1 & $.996^{\mathrm{a}}$ & .991 & .991 & .574 & 2.273 \\
\hline
\end{tabular}

Table 3 explains that the R Square (R2) value of 0.991 or $99.1 \%$ indicates the contribution of independent variables (Organizational culture, temperature, air, noise and lighting) while the remaining $0.9 \%$ is influenced by other factors not in this research model. Multiple correlation coefficients are used to measure the density of the relationship between independent and dependent variables. The coefficient of double correlation is indicated by a value $(\mathrm{R})$ of 0.996 or $99.6 \%$ 
indicating that independent variables (Organizational culture, temperature, air, noise and lighting) to patient satisfaction have a close relationship.

\section{DISCUSSION}

\section{A. Organizational Culture in Bangsal Public Health Center OF Mojokerto Regency}

The results of the study conducted on 397 respondents obtained data most of the respondents considered the organizational culture in the Mojokerto Regency Bangsal Health Center in a fairly good category as many as 278 respondents $(70 \%)$ and a small percentage consider the organizational culture in the category of less good as many as 58 respondents $(15 \%)$

The value system that is believed together is characteristic of the organization and becomes a reference for the members of the organization how to solve work problems and how to behave and behave. Value system is an organizational characteristic that can be used as a reference and guideline for employees in work. The value system is a reference for members of the organization in doing their work (Robbins, 2006 in Kholipah, 2013). The application of organizational culture in nursing includes the rapid application of knowledge and technology improvement in all fields as well as the increasing knowledge of the community also affects the increasing public demand for the quality of health services including nursing services. This is a challenge for the nursing profession in developing professionalism during providing quality services. High quality of service requires a strong foundation of commitment with a high ethical and moral basis. The robust professional ethical attitude of any nurse or midwife will be reflected in every step of the way, including self-appearance as well as decisions taken in response to emerging situations. Therefore a deep understanding of ethics and morals and its application become a very important and fundamental part in providing nursing or midwifery care where patient values are always considered and respected (Ardiansyah, 2010)

The results showed that the organizational culture applied in upt Puskesmas Bangsal Mojokerto regency in the category is quite good. This can be seen from the officers either nurses or midwives always provide optimal services such as they hear complaints from patients, be friendly to patients, and respond to whatever the patient complains about quickly and strive to provide appropriate responses. In addition, officers also try to help each other when it appears that one room is a lot of patients and the other officers are trying to direct patients to queue and sit in the queue in an orderly and not crowded so that services can be provided to the maximum. This shows that the officers in upt Puskesmas Bangsal Mojokerto either nurses, midwives or other officers try to apply the work with maximum results in accordance with the direction of the leadership and officers help each other in providing services so that the servants provided can be more optimal and fast.

Meanwhile, in respondents who stated the organizational culture in upt Puskesmas Bangsal Mojokerto in the category of less good happened because there are some officers who do not care about busy friends while he himself is not busy, there are nurses or midwives who are not friendly in serving patients and do not give smiles, are less responsive in responding to patient complaints and are less deft in providing actions to patients. This shows that although many respondents stated that the organizational culture in upt Puskesmas Bangsal in kateogri is quite good, but there are still respondents who state that the organizational culture is still not good because the officers do not pay much attention to the direction of the leadership in providing services to patients so that patients feel less well received

\section{B. Work Environment (temperature) in Bangsal Public Health Center OF Mojokerto Regency}

Based on the results of research on the work environment (temperature) in the Upt Puskesmas Bangsal Mojokerto obtained data Characteristics of the work environment (temperature) in the Upt Puskesmas Bangsal Mojokerto almost entirely work environment in the Puskesmas Bangsal in 
accordance with the standards set as many as 302 respondents $(76.1 \%)$ and a small percentage are less in accordance with existing standards as many as 95 respondents $(23.9 \%)$.

The work environment is the third level (3) of Maslow and the second level (2) of Alder, where one can interact with his colleagues, be accepted by his group and feel a familial connection or vice versa. The work environment can be interpreted in the physical form, namely buildings, rooms, neatness, cleanliness, facilities and other physical infrastructure. In addition, it can also be interpreted in psychological form, namely a comfortable, pleasant, saturated, or boring work atmosphere, lighting, temperature or temperature, security, decoration or noise (Hartono, 2012). Under normal circumstances, each member of the human body has a different temperature. The human body always strives to maintain a normal state, with a perfect body system so that it can adjust to changes that occur outside the body. But the ability to adjust has a limit, namely that the human body can still adjust itself to the outside temperature if the change in outside body temperature is not more than $20 \%$ for hot conditions and $35 \%$ for cold conditions, from the normal state of the body

Most of the respondents stated that the temperature in the service room at upt Puskesmas Bangsal Mojokerto regency was in accordance with the patient's expectations that it was not too hot and also not too cold. According to respondents the temperature in the service room of Puskesmas Bangsal was quite comfortable and paien did not feel hot or sultry. With this comfort respondents can receive good service. The presence of respondents who stated that the work environment is not suitable occurs because respondents still feel uncomfortable in entering the service room at upt Puskesmas Bangsal Mojokerto Regency, which can be seen from the room temperature that still feels a bit hot because it only uses a fan to so that respondents who are used to air conditioning feel less cool in the room

\section{Work Environment (air) in Bangsal Public Health Center OF Mojokerto Regency}

Based on the results of research on the work environment in upt Puskesmas Bangsal Mojokerto obtained data Characteristics of the work environment (air) in upt Puskesmas Bangsal Mojokerto almost entirely air circulation in the Puskesmas Bangsal in accordance with the standard set as many as 230 respondents (57.9\%) and a small percentage did not comply with the existing standards of 31 respondents $(7.8 \%)$.

The work environment is the third level (3) of Maslow and the second level (2) of Alder, where one can interact with his colleagues, be accepted by his group and feel a familial connection or vice versa. The work environment can be interpreted in the physical form, namely buildings, rooms, neatness, cleanliness, facilities and other physical infrastructure. In addition, it can also be interpreted in psychological form, namely a comfortable, pleasant, saturated, or boring work atmosphere, lighting, temperature or temperature, air ventilation or humidity, safety, decoration or noise (Hartono, 2012). Temperatures and humidity that have been in accordance with permitted standards will result in the comfort of the workforce and will be able to increase the productivity of the workforce. In addition to this, the hospital is a place where the sick are the source of disease transmission. If the temperature has been low and humidity is too high will be able to facilitate the breeding of bacteria, fungi, viruses and various other disease seeds. Thus, if the temperature and humidity are not properly observed, it will be able to cause harm to the

patients and health care facilities themselves (Sedamaryanti, 2012).

According to respondents, the humidity in the service room of upt Puskesmas Bangsal Mojokerto regency is in accordance with patient expectations. The air vents in each service room meet ideal standards, because each room has glass windows that can be opened and the air can enter coolly and not stuffy, so that the patient feels comfortable even though they are indoors. In addition, health workers can also work well so that work productivity increases so that officers can provide optimal service to patients and can provide satisfaction to patients. The existence of respondents who stated the work environment (air) is not appropriate because respondents still feel uncomfortable in entering the service room at the Upt Puskesmas Bangsal Mojokerto Regency. The discomfort felt by 
respondents because they are accustomed to the cool and cold room conditions so that when respondents in a room that does not use air conditioning, respondents feel uncomfortable

\section{Work Environment (noise) in Bangsal Public Health Center OF Mojokerto Regency}

Based on the results of research on the work environment in upt Puskesmas Bangsal Mojokerto obtained data Characteristics of the work environment (noise) in upt Puskesmas Bangsal Mojokerto almost all respondents stated the service room in Puskesmas Bangsal in accordance with the standard set as many as 230 respondents $(57.9 \%)$ and almost half were not in accordance with the standards of 167 respondents $(57.9 \%)$.

Service organizations are required to be able to optimize the service resources it manages. Management of service resources can not be separated from labor factors, facilities, service work environment and others that are expected to provide the best possible services in order to achieve the goals and progress of the organization. Service facilities for service organizations are the main assets of the organization, and have a strategic role in the organization, namely as facilities, infrastructure, tools and places of control of organizational activities, facilities and work environment of service organizations reflected in the existence of buildings, places, infrastructure facilities, tools, fittings, support services and surrounding environmental conditions (Hermanto, 2016). One component of the physical environment that interferes with comfort is noise. noise that our ears do not want. Noise is not desirable because in the long run it can disturb the calm (Sedamaryanti, 2012).

Most of the respondents stated that the noise level in the service room at upt Puskesmas Bangsal Mojokerto regency was in accordance with the patient's expectations. Noise pollution in the service room is still included in the category of normal or standard so that it does not interfere with the comfort of patients, and the communication process between the officer and the patient can run smoothly, so that the patient can understand the explanation given by the health center officer. There were respondents who stated that the noise level was still not in accordance with the standards because at the time the respondents visited the condition around the puskesmas was in a crowded state of visitors and also the location of the puskesmas was close to the provincial highway at that time the traffic conditions were crowded, so the patient felt a little disturbed by the disturbance from outside the puskesmas.

\section{E. Work Environment (lighting) in Bangsal Public Health Center OF Mojokerto Regency}

Based on the results of research on the work environment in upt Puskesmas Bangsal Mojokerto obtained data Characteristics of the work environment (lighting) in upt Puskesmas Bangsal Mojokerto almost entirely work environment (lighting) in puskesmas Bangsal in accordance with the standard set as many as 296 respondents $(74.6 \%)$ and hamper half of them are not in accordance with existing standards as many as 101 respondents $(25.4 \%)$

The ability of the eye to see an object is clearly influenced by the size of the object, the degree of contrast between the object and its surroundings, luminance (brightness), and the length of time it takes to see the object. To avoid glare due to the incorrect laying of light sources, it is recommended that the light source be placed in such a way that the light hits the object to be seen first which is then reflected by the object into our eyes. In relation to lighting problems, means that the standard of lighting that can be used as a benchmark in this inpatient room is the standard of lighting of people in general, where the standard for sick people is considered no different from the standard for healthy people (Sedamaryanti, 2012).

Most of the respondents in this study stated that the lighting condition in the service room of upt Puskesmas Bangsal Mojokerto regency is in accordance with patient expectations. Lighting or lighting the room will greatly affect the ability of humans to see objects clearly, quickly and without causing errors. Lack of lighting will cause the eyes to become tired quickly because the eyes will try to see clearly by opening wide. Eye fatigue will result in mental fatigue and eye damage. Good 
lighting will be able to increase the work productivity of officers to be more optimal and not cause eye fatigue, so that officers can provide good service. In addition, the impact of good lighting on patients will help patients receive information in the form of pictures or writing better because the patient does not open their eyes too wide or bring the writing closer received, so they feel quite comfortable with the service

\section{F. Patient Satisfaction in Bangsal Public Health Center OF Mojokerto Regency}

Patient satisfaction characteristics showed that most respondents were satisfied with the services provided by 147 respondents (37\%) and a small percentage expressed dissatisfaction as many as 99 respondents $(25 \%)$.

Customer satisfaction is central to the goal of marketing concepts. So that all marketing planning and programs of a company aims to satisfy customers. Because customers will pay attention to the quality of service provided by the company (Laurent, 2005). Satisfaction is the level of a person's feelings after comparing performance or perceived results in accordance with his expectations (Supranto, 2012).

The results of this study showed that many patients are satisfied with the form of service received by patients, especially on the skills of officers and the response provided by officers in responding to patient complaints, in addition officers are also friendly to patients so that patients feel comfortable in receiving services provided by officers. According to patient officers at upt Puskesmas Bangsal Mojokerto always appropriate in providing information and therapy to patients and they do not wait for patients to remind the time to re-visit and take medication. In addition, patients feel that the officers pay more attention to the patient for example they always invite the patient to talk when giving therapy so that the susaana becomes less tense and the provision of therapy becomes smooth. While in patients who feel less happens because there are still respondents who consider nurses who are less friendly, nurses there are differentiating the provision of services to patients with each other, when providing therapy they look rigid and the response given seems still long

\section{G. Relationship of Organization Culture with Patient Satisfaction in Bangsal Public Health Center OF Mojokerto Regency}

Based on partial tests on table 1 showed that the $\mathrm{p}$ value of both independent variables (Organizational culture, temperature, air, noise and lighting) was less than 0.05 so that partially or on its own independent variables (Organizational culture, temperature, air, noise and lighting) affected patient satisfaction.

The results of this study were supported by Kholipah research (2013) which showed that the application of organizational culture was weak as many as 47 respondents (47.5\%) and application of strong organizational culture as many as 52 respondents $(52.5 \%)$. Low patient satisfaction as many as 32 respondents $(32.3 \%)$ and high patient satisfaction as many as 67 respondents $(67.7 \%)$. There is a relationship between the application of organizational culture and patient satisfaction at Ambarawa Hospital ( $\mathrm{p}$ value $0.007, \alpha=0.05$ )

Mubarok (2012) stated that the lack of satisfaction means that the needs of patients in terms of health services have not been met, thus bringing a feeling of dissatisfaction in respondents. The level of patient satisfaction according to is influenced by the timeliness, communication, confidence of a nurse, technical competence concerning the skills, ability and appearance or performance of health care providers, affordability and interpersonal relationships. Nurse communication to the patient, even if it has been done, but if it is not systematic and therapeutic, will be able to affect the level of patient satisfaction.

The results of this study showed that the application of a strong organizational culture of the officers in Puskesmas Bangsal can affect the satisfaction of the services received by patients. The application of a strong organizational culture including officers trying to complete work such as the 
provision of actions and administration of applicants quickly and appropriately so that patients feel that the officers in puskesmas have good skills and can be trusted in providing services. This emerging trust can be a cause of patient satisfaction in receiving health care. However, in the room officers who are still slow in providing services and less deft in providing actions will cause negative perceptions of patients so that patients are not satisfied with the services received.

\section{H. Relationship of Work Environment (Temperature, air, noise, lighting) with Patient Satisfaction in Bangsal Public Health Center OF Mojokerto Regency}

Based on the partial test results in table 1 shows that the $p$ value of both independent variables (Organizational culture, temperature, air, noise and lighting) is less than 0.05 so that partially or on its own independent variables (Organizational culture, temperature, air, noise and lighting) affect patient satisfaction.

The results of this study were supported by Dahar research (2015) which showed that the results of correlation analysis and simple linear regression showed that the work environment has a positive and significant effect on the quality of health services and patient satisfaction with a degree of determination of $38.9 \%$.

According to Sukanto and Indriyo (2014) "the work environment is everything around workers that can influence in work including lighting arrangements, noise control, workplace hygiene settings and workplace safety arrangements." According to Nitisemito (2011) the work environment is "everything that is around the workers and can affect him in carrying out the tasks that are burdened". Service organizations are required to be able to optimize the service resources it manages. Management of service resources can not be separated from labor factors, facilities, service work environment and others that are expected to provide the best possible services in order to achieve the goals and progress of the organization. Service facilities for service organizations are the main assets of the organization, and have a strategic role in the organization, namely as facilities, infrastructure, tools and places of control of organizational activities, facilities and work environment of service organizations reflected in the existence of buildings, places, infrastructure facilities, tools, fittings, support services and surrounding environmental conditions (Hermanto, 2016).

The results of this study showed that physical work environments such as temperature, lighting, air noise and lighting can affect patient satisfaction. In hot air temperatures will cause patients to feel uncomfortable in receiving services indoors so that the officers in providing services will look hasty and sometimes seem less thorough or skilled so that the patient feels uncomfortable in receiving the service. In the problem of noise can also affect patient satisfaction, where in a room that is too noisy then the communication created between the patient and the officer will not run well and sometimes can be unclear so that the patient feels uncomfortable and less clear in receiving information related to the health condition experienced, the officer is also less able to respond to the patient because of the lack of clear information conveyed by the patient to the officer. Room lighting can also affect patient satisfaction where in lighting that is lacking officers will not be able to provide action or service to the maximum because of limited activity in less bright spaces.

\section{Relationship of Organization Culture and Work Environment (Temperature, air, noise, lighting) with Patient Satisfaction in Bangsal Public Health Center OF Mojokerto Regency}

Based on table 2 shows that the significance value indicates a value $=0.000$ which means less than 0.05 so that it can be expressed simultaneously or simultaneously independent variables (Organizational culture, temperature, air, noise and lighting) affecting patient satisfaction. While in table 3 it explains that the value of R Square (R2) is 0.991 or $99.1 \%$ which indicates the contribution of independent variables (Organizational culture, temperature, air, noise and lighting) while the remaining $0.9 \%$ is influenced by other factors that are not in this research model. Multiple correlation coefficients are used to measure the density of the relationship between independent and dependent 
variables. The coefficient of multiple correlations is indicated by a value (R) of 0.996 or $99.6 \%$ indicating that independent variables (Organizational culture and work environment) to patient satisfaction have a very close relationship.

The results of this study were supported by Maulana's research (2017) which showed the results of research on the influence of the work environment on the job satisfaction of employees of upt Puskesmas Tembilahan Kota obtained a coefficient of determination (R2) is $50.1 \%$ of the work environment influenced by job satisfaction and the remaining $49.9 \%$ influenced by factors other than those examined. Sulistiawan (2017) also supported the results of this study which showed that R value of 0.886 or $88.6 \%$ which means the level of closeness of relationship between employee performance variable (Y) and Organizational Culture (X1) and Work Environment (X2) based on correlation interpretation table is strong.) The coefficient of determination (R2) of $0.784(0.784 \times 100 \%)$, this indicates the proportion that can be explained by independent variables (organizational culture and work environment) is $78.4 \%$, while the remaining $21.6 \%$ is explained by other variables not included in this research model.

Sedarmayanti (2012) defines organizational culture as a belief, attitude and value that is generally possessed, arising in the organization, put forward more simply, culture is the way we do things here. Meanwhile, According to Robbins (2012) Physical condition has a role to do with the behavior or attitude of the working group. In general a worker prefers a neat, clean, comfortable environment, appropriate temperature and lighting, sophisticated and modern equipment, and so on. Good performance will not be obtained by dirty, dusty tables, messy atmosphere, hot air, blinding light and so on.

The results of this study show that the application of a strong organizational culture by officers who provide services to patients in upt Puskesmas Bangsal Mojokerto will affect the comfort of patients in receiving health services so that patients will feel satisfied with the services provided by the officers. While reviewed from the work environment shows that the existence of a neat work environment, clean, cool air, comfortable and not glare and not too noisy will be able to affect the relationship between patients and officers to be better because the communication is created clearly and well so that the services provided by officers can be in accordance with patient complaints and patient expectations. This can foster the satisfaction of patients in receiving services given by officers at upt Puskesmas Bangsal Mojokerto Regency

\section{CONCLUSION}

1. Organizational culture in Bangsal Public Health Center Of Mojokerto regency most respondents consider the organizational culture a fairly good category as many as 152 respondents (38.3\%)

2. Characteristics of the work environment (temperature) in Bangsal Public Health Center Of Mojokerto regency almost entirely work environment (temperature) in accordance with the standard set by 302 respondents $(76.1 \%)$

3. Characteristics of the work environment (air) in Bangsal Public Health Center Of Mojokerto regency almost entirely air circulation in accordance with the standard set by 230 respondents $(57.9 \%)$

4. Characteristics of the work environment (noise) in Bangsal Public Health Center Of Mojokerto regency almost all respondents stated the service room in accordance with the standard set by 230 respondents $(57.9 \%)$.

5. Characteristics of the work environment (lighting) in Bangsal Public Health Center Of Mojokerto regency almost entirely work environment (lighting) in accordance with the standard set as many as 296 respondents $(74.6 \%)$. 
6. Patient satisfaction at Bangsal Public Health Center Of Mojokerto regency district showed that most respondents were satisfied with the services provided by 147 respondents (37\%)

7. There is a partial influence of organizational culture and work environment with patient satisfaction in Bangsal Public Health Center Of Mojokerto regency indicated by p value $<0.05$

8. There is a simultaneous influence of organizational culture and work environment with patient satisfaction in Bangsal Public Health Center Of Mojokerto regency which is indicated by p value $<0.05$.

\section{SUGGESTIONS}

1. For the Management of puskesmas, especially on the Head of Puskesmas to be able to put more emphasis on the staff or officers below about the importance of the application of organizational culture in providing services to patients and also the importance of good environmental arrangement, neat, clean and comfortable so that the services provided can satisfy patients..

2. Officers need to increase understanding of how services should be provided to patients who are good enough and quality such as providing fast service through participation in training, seminars and coaching as well as from reading books and more motivated in performing health services in patients.

3. Further research should be done with a longer research implementation time so as to describe the circumstances and practices carried out by the officers daily in providing services and akhrinya research results can be obtained to the maximum and can help develop science and technology in the field of health

\section{CONFLICT OF INTEREST}

No potential conflict of interest was reported by authors. The source of research funding is from the researchers themselves.

\section{ACKNOWLEDGMENTS}

The author would like thank to head and all staff of internist Poly At Dr. Moedjito Dwijosiswodjo Hospital, friends of IIK STRADA Indonesia Kediri students, and all parties who have helped the smooth writing of this thesis which cannot be mentioned one by one. No potential conflict of interest was reported by authors.

\section{REFERENCE}

Ardiansyah, 2010. Manajemen sumber daya manusia Edisi Kesepuluh. Jakarta : PT. Indeks. Azwar, A. 2011. Pengantar Administrasi Kesehatan. Tangerang : Binarupa aksara

Dahar, Viviant. 2015. Pengaruh Lingkungan Kerja Terhadap Kualitas Pelayanan. Urnal Administrasi Publik. Vol 3 No. 038

Hartono Sri. 2012. Manajemen Sumber Daya Manusia. Ponorogo : UMPO Pres

Herawati Nunuk., dan Qomariyah Nur. 2015. Pengaruh Kualitas Pelayanan Puskesmas terhadap Kepuasan pasien Pengguna Kartu Pemeliharaan Kesehatan Masyarakat Surakarta (PKMS) di Surakarta. Bhirawa Vol. 2 No. 2 Edisi Desember 2015

Hermanto. 2016. Public Relations dalam Organisasi. Yogyakarta: Sansusta.

Kholipah, Siti. 2013. Hubungan Penerapan Budaya Organisasi Dengan Kepauasan Pasien Di RSUD Ambarawa. Jurnal Manajemen Keperawatan Bol. 1 No. 1 Mei 2013

Kotler, Philip dan Armstrong, Gary. 2012. Principles of Marketing (Fourteenth Edition). England: Pearson Education Limited 
Laurent K. Wright, 2005. Pemasaran Jasa. Jakarta: Gramedia

Maulana Agus. 2017. Pengaruh Lingkungan Kerja Terhadap Kepuasan Kerja Karyawan UPT Puskesmas Tembilahan Kota. Jurnal Manajemen Kesehatan Vol.3 No.2 Juli 2017

Moekijat. 2015. Latihan dan Pengembangan Sumber Daya Manusia. Bandung : Bandar Maju

Mubarak, Wahit Iqbal, 2012. Pengantar Keperawatan Komunitas. Jakarta : CV Sagung seto

Munanzar. 2019. Analisis Budaya Organisasi Dan Kualitas Pelayanan Publik. Jurnal Sosial Budaya Vol. 3 No 42020.

Nilawati. 2019. Pengaruh Perilaku Konsumen Terhadap Keputusan Pembelian Dalam Menggunakan Jasa Go-Jek Online Di Kota Medan. Jurnal Ekonomi Dan Bisnis UISU, VOl 3 No 9

Nitisemito, Alex. 2011 Manajemen Personalia (Manajemen Sumber Daya Manusia, Edisi Kelima, Cetakan Keempat belas. Jakarta : Ghalia Indonesia.

Robbins. Stephen. 2012. Perilaku Organisasi. Edisi Bahasa Indonesia. Jakarta : Prehalindo.

Sari, U. P. 2016. Pengaruh Fasilitas, Lingkungan Kerja Dan Motivasi Terhadap Kinerja Pegawai Di Kantor Camat Sangatta Selatan Kabupaten Kutai Timur. EJournal Pemerintahan Integratif, 4(4), 505-519

Sedarmayanti. 2012. Sumber Daya Manusia dan Produktivitas Kerja. Bandung : Mandar Maju

Sukanto Reksohadiprodjo dan Indriyo, Gitosudarmo. 2014. Manajemen Produksi. Edisi 4. Yogyakarta : BPFE

Sulistiawan, Deni. Riadi, Sukisno S, Maria, Siti. 2017. Pengaruh Budaya Organisasi Dan Lingkumgam Kerja Terhadap Kinerja Pegawai. Jurnal Volume 14 Nomor 2.

Supranto, 2012, Pengukuran Tingkat Kepuasan Pelanggan : Untuk Menaikkan. Pangsa Pasar, Jakarta, Rineka Cipta

Winarsih. Atik Septi, 2012, Manajemen Pelayanan : Pengembangan Modul Konseptual, Penerapan Citizen Charter dan Standar Pelayanan Minimal, Yogyakarta : Pustaka Pelajar

Yulfita,Andari E. 2016. Analisi Kualitas Pelayanan Terhadap Kepuasan Pasien Berobat Di Puskesmas Pembantu Pasir Utama. Ilmiah Cano Economas Vol. 45 No. 12017 